\title{
ANALISIS STRATEGI GURU DALAM MENINGKATKAN MOTIVASI BELAJAR SISWA
}

\author{
Amiratul Muzeeb Aditya ${ }^{1}$, Arif Rahman Setyadi ${ }^{2}$, Rizki Leonardho ${ }^{3}$ \\ Universitas muhammadiyah tangerang \\ Arifrahmans3257@gmail.com
}

\begin{abstract}
This study aims to understand teacher strategies in increasing student motivation. This research uses qualitative case study research. In this study the researchers collected descriptive data obtained from data collection through observation, interviews and documentation. Analysis of basic teacher skills in implementing thematic learning in elementary thematic learning can be done comprehensively and deeply. In order for students to have high motivation, various efforts need to be made by the teacher to encourage that motivation. Explaining the benefits or objectives of the lesson that students actually receive will encourage student motivation. Everyone suggests something to do. With motivation will grow the urge to do something in his agreement.
\end{abstract}

Keywords: Teacher Skills, Teacher Thematic Settings, Elementary Schools

\begin{abstract}
Abstrak : Penelitian ini bertujuan untuk mengetahui strategi guru dalam meningkatkan motivasi siswa. Penelitian ini menggunakan penelitian studi kasus kualitatif. Dalam penelitian ini para peneliti mengumpulkan data deskriptif yang diperoleh dari pengumpulan data melalui observasi, wawancara dan dokumentasi. Analisis kemampuan guru sekolah dasar dalam implementasi pembelajaran tematik di SD pembelajaran tematik dapat dilakukan secara komprehensif dan mendalam. Agar para siswa memiliki motivasi yang tinggi, beberapa usaha perlu dilakukan oleh guru untuk membangkitkan motivasi tersebut. Menjelaskan manfaat atau tujuan dari pelajaran yang betul-betul dirasakan siswa akan membangkitkan motivasi belajar siswa. Sebagaimana telah dikemukakan motivasi merupakan suatu dorongan yang menyebabkan seseorang melakukan sesuatu. Dengan motivasi akan tumbuh dorongan untuk melakukan sesuatu dalam kaitannya pencapaian tujuan.
\end{abstract}

Kata Kunci: Keterampilan Guru, Pendekatan Tematik Guru, Sekolah Dasar

Manazhim : Jurnal Manajemen dan Ilmu Pendidikan

Volume 2, Nomor 1, Februari 2020; 97-104

https://ejournal.stitpn.ac.id/index.php/manazhim 


\section{PENDAHULUAN}

Pendidikan merupakan usaha sadar yang sengaja dirancang pemerintah untuk mencapai tujuan yang ditetapkan. Salah satu tujuan pendidikan itu sendiri untuk meningkatkan kualitas sumber daya manusia yang berkualitas. Menurut Sahertian, "salah satu usaha yang ditempuh untuk meningkatkan kualitas sumber daya manusia adalah melalui proses pembelajaran di sekolah". ${ }^{1}$ Dalam keseluruhan proses proses pendidikan di sekolah, kegiatan belajar merupakan kegiatan yang paling pokok. "Berhasil tidaknya pencapaian tujuan pendidikan banyak bergantung pada proses belajar yang dialami oleh siswa sebagai anak didik". ${ }^{2}$

Menurut Hamali, Kegiatan belajar merupakan proses penting di dalam perkmbangan perilaku dan kepribadian siswa. "Proses belajar dan hasil belajar para siswa bukan saja ditentukan oleh sekolah, pola, struktur, dan isi kurikulumnya akan tetapi sebagian besar ditentukan oleh kompentensi guru yang mengajar dan membimbing mereka". ${ }^{3}$ Usman juga mengatakan, "Oleh karena itu guru memegang peranan penting dalam menentukan kualitas dan kuantitas pengajaran yang dilaksanakan untuk mencapai hasil belajar siswa yang optimal". ${ }^{4}$

Strategi guru dalam proses belajar mengajar dalam pendekatan terhadap pendidikan diperlukan seperangkat metode pengajaran untuk melaksanakan tujuan pembelajaran. Untuk melaksanakan metode pembelajar tersebut dibutuhkan seperangkat kebutuhan yang harus dimiliki oleh seorang guru. "Suatu program pengajaran yang disenggelarakan oleh guru dalam satu tatap muka, bisa dilaksanakan dengan berbagai metode seperti ceramah,diskusi kelompok, maupun tanya jawab". ${ }^{5}$

Penggunaan strategi guru dalam mengajar sangat diperlukan untuk mempermudah proses pembelajaran siswa sehingga dapat mencapai hasil belajar yang optimal. Tanpa strategi yang jelas, proses belajar mengajar tidak akan terarah sehingga tujuan pembelajaran yang telah ditetapkan tidak berlangsung sesuai dengan rencana.

${ }^{1}$ Sahertian. 2008. Konsep Dasar dan Teknik Supervisi Pendidikan dalam rangka Pengembanagan Sumber daya Manusia. Jakarta: Rineka Cipta.

2 Slameto. 2003. Belajar dan Faktor-faktor yang Mempengaruhinya. Jakarta: Rineka Cipta.

${ }^{3}$ Hamalik, Oemar.2008. Perencanaan Pengajaran Berdasarkan Pendekatan Sistem. Jakarta: Bumi Aksara.

${ }^{4}$ Moh. Uzer Usman, 2008, Strategi Pembelajaran, Jakarta : Erlangga

${ }_{5}^{5}$ Gulo, W. 2002. Metode Penelitian. Jakarta: PT. Grasindo. 
Srategi mengajar bagi guru merupakan pedoman dan acuan bertindak yang sistematis dalam pelaksanaan proses disekolah.

Pada dasarnya terdapat berbagai faktor yang mempengaruhi keberhasilan pendidikan, antara lain: guru, siswa, sarana dan prasarana, lingkungan pendidikan, kurikulum. Dari beberapa faktor tersebut, guru dalam kegiatan proses pembelajaran di sekolah menempati kedudukan yang sangat penting dan tanpa mengabaikan faktor penunjang yang lain, guru sebagi subyek pendidikan sangat menentukan keberhasilan pendidikan itu sendiri. Studi yang dilakukan Heyneman \& Loxley pada tahun 1983 di 29 negara menemukan bahwa di antara berbagai masukan (input) yang menentukan mutu ssb (yang ditunjukkan oleh prestasi belajar siswa) sepertiganya ditentukan oleh guru. Peranan guru makin penting lagi di tengah keterbatasan sarana dan prasarana sebagaimana dialami oleh negara-negara sedang berkembang. Lengkapnya hasil studi itu adalah : di 16 negara sedang berkembang, guru memberi kontribusi terhadap prestasi belajar sebesar $34 \%$, sedangkan manajemen $22 \%$, waktu belajar 18\% dan sarana fisik 26\%. Di 13 negara industri, kontribusi guru adalah 36\%, manajemen 23\%, waktu belajar 22\% dan sarana fisik $19 \%{ }^{6}$. Hasil penelitian yang dilakukan oleh Nana Sudjana menunjukkan bahwa 76,6\% hasil belajar siswa dipengaruhi oleh kinerja guru, dengan rincian: kemampuan guru mengajar memberikan sumbangan 32,43\%, penguasaan materi pelajaran memberikan sumbangan 32,38\% dan sikap guru terhadap mata pelajaran memberikan sumbangan $8,60 \% .^{7}$

Harus diakui bahwa guru merupakan faktor utama dalam proses pendidikan. Meskipun fasilitas pendidikannya lengkap dan canggih, namun bila tidak ditunjang oleh keberadaan guru yang berkualitas, maka mustahil akan menimbulkan proses belajar dan pembelajaran yang maksimal. 8:

1). Guru sebagai pelaksana pendidikan nasional merupakan faktor kunci.

Peningkatan prestasi belajar siswa akan dipengaruhi oleh kualitas proses pembelajaran di kelas. Oleh karena itu untuk meningkatkan prestasi belajar siswa, proses pembelajaran di kelas harus berlangsung dengan baik, berdaya guna dan berhasil guna. Proses pembelajaran akan berlangsung dengan baik apabila didukung oleh guru yang mempunyai kompetensi dan kinerja yang tinggi, karena guru merupakan ujung tombak dan pelaksana terdepan

${ }^{6}$ Dedi Supriyadi. 1999. Mengangkat Citra dan Martabat Guru. Adicita Karya Nusa, Yogyakarta. ${ }^{7}$ Nana sudjana. (2002).Penilaian Hasil Proses Belajar Mengajar. Bandung: Remaja Rosdakarya.

${ }^{8}$ Utami, Neni. 2003. Kualitas dan Profesionalisme Guru. Artikel dari http://www.pikiranrakyat.com/cetak/102/15/0802htm 
pendidikan anak-anak di sekolah, dan sebagai pengembang kurikulum. Guru yang mempunyai kinerja yang baik akan mampu menumbuhkan semangat dan motivasi belajar siswa yang lebih baik, yang pada akhirnya akan mampu meningkatkan kualitas pembelajaran. ${ }^{9}$

Motivasi belajar siswa dapat dibedakan menjadi dua, yaitu motivasi intern (internal motivation) dan motivasi ekstern (external motivation). Motivasi intern muncul karena adanya faktor dari dalam, yaitu karena adanya kebutuhan, sedangkan motivasi ektern muncul karena adanya faktor dari luar, terutama dari lingkungan. Dalam kegiatan pembelajaran faktor eksternal yang mampu mempengaruhi motivasi belajar siswa adalah kinerja guru.

\section{Teknik Pengumpulan Data}

\section{Metode dan teknik pengumpulan data}

Metode pengumpulan data merupakan alat penting dalam suatu penelitian yang bertujuan untuk mendapatkan data yang diperlukan. Metode pengumpulan data dalam penelitian ini menggunakan 2 metode, yaitu :

\section{Metode Observasi}

Observasi merupakan pengamatan secara sistematis, yaitu pengamatan yang dilakukan dengan menggunakan pedoman observasi sebagai instrument pengamatan yang telah dirancang tentang apa yang telah diamati dan dimana tempatnya.

2. Wawancara

Wawancara dalam penelitian ini digunakan sebagai kelengkapan untuk memperoleh data tentang kendala-kendala yang dihadapi selama penggunaan observasi. Teknik wawancara dikemukakan secara bebas, artinya kalimat atau pertanyaan tidak terpaku pada pedoman wawancara yang ada, namun pertanyaan dapat diperdalam dan dikembangkan sesuai dengan kondisi dilapangan .

Penelitian ini dilaksanakan di Sekolah Dasar yang terletak di SDN Doyong 2 Tangerang Subjek dalam penelitian ini adalah guru kelas VI. Jadi dalam studi kasus ini, peneliti tidak mengambil secara keseluruhan komponen-komponen yang ada di

${ }_{9}^{9}$ Depdikbud, 1991. Kamus Besar Bahasa Indonesia, Jakarta: Balai Pustaka. 
SDN Doyong 2. Penelitian hanya dibatasi terkait dengan proses pembelajaran tematik, serta seluruh aktivitas guru dan siswa selama dalam proses pembelajaran.

\section{Partisipan}

Yang menjadi partisipan dalam penelitian ini adalah guru kelas SDN Doyong 2

\section{Instrumen}

Instrumen dalam penelitian ini digunakan pedoman observasi dan dokumentasi serta butir-butir pertanyaan dalam wawancara

\section{Teknik Analisis Data}

Teknik analisis data yang digunakan dalam penelitian ini adalah analisis deskriptif, artinya data yang diperoleh dalam penelitian ini disajikan apa adanya kemudian dianalisis secara deskriptif untuk mendapatkan gambaran mengenai fakta yang ada.

\section{HASIL DAN PEMBAHASAN}

\section{Hasil}

Salah satu faktor yang mempengaruhi kualitas pembelajaran adalah variabel guru. Guru mempunyai pengaruh yang cukup dominan terhadap kualitas pembelajaran, karena gurulah yang bertanggung jawab terhadap proses pembelajaran di kelas, bahkan sebagai penyelenggara pendidikan di sekolah. Menurut Dedi Supriyadi, di antara berbagai masukan (input) yang menentukan mutu pendidikan (yang ditunjukkan oleh prestasi belajar siswa) sepertiganya ditentukan oleh guru. Faktor guru yang paling dominan mempengaruhi kualitas pembelajaran adalah kinerja guru. ${ }^{10}$ Hasil penelitian yang dilakukan oleh Nana Sudjana menunjukkan bahwa 76,6\% hasil belajar siswa dipengaruhi oleh kinerja guru, dengan rincian: kemampuan guru mengajar memberikan sumbangan 32,43\%, penguasaan materi pelajaran memberikan sumbangan 32,38\% dan sikap guru terhadap mata pelajaran memberikan sumbangan 8,60\%. ${ }^{11}$ Menurut Cruickshank, kinerja guru yang mempunyai pengaruh secara langsung terhadap proses pembelajaran adalah kinerja guru dalam kelas atau teacher classrroom performance. ${ }^{12}$

\footnotetext{
${ }^{10}$ Dedi Supriyadi. 1999. Mengangkat Citra dan Martabat Guru. Adicita Karya Nusa, Yogyakarta.

${ }^{11}$ Nana sudjana. (2002).Penilaian Hasil Proses Belajar Mengajar. Bandung: Remaja Rosdakarya.

12 Anderson, W Lorin., Krathwohl, R. David, W Peter., Cruikshank A. Kathleen., Richard E Mayer., Pintrich R Paul., Rath James., Wiftrock C Marlian. 2001. A. Taxonomy for Learning, Teaching and
} 
Berdasarkan pendapat tersebut di atas diketahui bahwa kinerja guru merupakan faktor yang dominan dalam menentukan kualitas pembelajaran. Artinya kalau guru yang terlibat dalam kegiatan pembelajaran mempunyai kinerja yang bagus, akan mampu meningkatkan sikap dan motivasi belajar siswa yang pada akhirnya akan meningkatkan kualitas pembelajaran, begitu juga sebaliknya. Kinerja guru yang berpengaruh terhadap motivasi belajar siswa adalah kinerja guru dalam kelas. Meningkatnya kualitas pembelajaran, akan mampu meningkatkan hasil belajar siswa. Hal ini dapat dipahami karena guru yang mempunyai kinerja bagus dalam kelas akan mampu menjelaskan pelajaran dengan baik, mampu menumbuhkan motivasi belajar siswa dengan baik, mampu menggunakan media pembelajaran dengan baik, mampu membimbing dan mengarahkan siswa dalam pembelajaran sehingga siswa akan memiliki semangat dalam belajar, senang dengan kegiatan pembelajaran yang diikuti, dan merasa mudah memahami materi yang disajikan oleh guru.

\section{Pembahasan}

Dalam penelitian ini motivasi belajar siswa difokuskan pada motivasi berprestasi. Motivasi berprestasi diartikan sebagai dorongan untuk mengerjakan suatu tugas dengan sebaik-baiknya berdasarkan standar keunggulan. Motif berprestasi bukan sekadar dorongan untuk berbuat, tetapi juga mengacu pada suatu ukuran keberhasilan berdasarkan penilaian terhadap tugas-tugas yang dikerjakan seseorang. Motivasi berprestasi merupakan dorongan memperoleh suatu hasil dengan sebaik- baiknya agar tercapai perasaan kesempurnaan pribadi. Dengan demikian, perilaku di sini berkaitan dengan harapan (expectation). Harapan seseorang terbentuk melalui belajar dan selalu mengandung standar keunggulan. Standar tersebut mungkin berasal dari tuntutan orang lain atau lingkungan tempat seseorang dibesarkan. Oleh karena itu, standar keunggulan merupakan kerangka acuan bagi individu yang bersangkutan pada saat ia belajar, menjalankan tugas, memecahkan masalah maupun mempelajari sesuatu. Adapun ciri-ciri motivasi berprestasi ada empat, yaitu:1) berorientasi pada keberhasilan, 2) bertanggung jawab, 3) inovatif, dan 4) mengantisipasi kegagalan.

Assesing. A Revision of Bloom's Taxonomy of Educational Objective. Abridged Edition. New York : Logman Inc. 


\section{KESIMPULAN}

Pada temuan penelitian di atas yang telah di uraikan dapat dirumuskan simpulan Strategi guru dalam proses belajar mengajar dalam pendekatan terhadap pendidikan diperlukan seperangkat metode pengajaran untuk melaksanakan tujuan pembelajaran. Analisis kemampuan guru sekolah dasar dalam implementasi pembelajaran tematik di SD pembelajaran tematik dapat dilakukan secara komprehensif dan mendalam. Agar para siswa memiliki motivasi yang tinggi, beberapa usaha perlu dilakukan oleh guru untuk membangkitkan motivasi tersebut. Menjelaskan manfaat atau tujuan dari pelajaran yang betul-betul dirasakan siswa akan membangkitkan motivasi belajar siswa. Sebagaimana telah dikemukakan motivasi merupakan suatu dorongan yang menyebabkan seseorang melakukan sesuatu. Dengan motivasi akan tumbuh dorongan untuk melakukan sesuatu dalam kaitannya pencapaian tujuan.

Seorang guru sebaiknya memiliki rasa ingin tahu, mengapa dan bagaimana anak belajar dan menyesuaikan dirinya dengan kondisi-kondisi belajar dalam lingkungannya. Hal tersebut akan menambah pemahaman dan wawasan guru sehingga memungkinkan proses pembelajaran berlangsung efektif dan optimal, karena pengetahuan kejiwaan anak yang berhubungan dengan masalah pendidikan bias dijadikan dasar dalam memberikan motivasi kepada peserta didik sehingga mau dan mampu belajar dengan sebaik-baikny

\section{DAFTAR PUSAKA}

Anderson,WLorin, Krathwohl, R. David, W Peter, Cruikshank A, Kathleen, Richard E Mayer, dkk. (2001). A Taxonomy for Learning Teaching and Assesing A Revision of Bloom's Taxonomy of Educational Objective. Abridged Edition. New York: LogmanInc

Dapartemen Pendidikan Nasional ( 2004 ). Pengembangan perangkat penilaiain kinerja guru, Jakarta ditjen dikti, bagian proyek P2TK.

Dedi Supriyadi. (1999). Mengangkat Citra dan Martabat Guru. Adicita Karya Nusa, Yogyakarta.

Depdikbud. (1991). Kamus Besar Bahasa Indonesia. Jakarta: Balai Pustaka. 
Disertasi doctor, tidak diterbitkan Universitas Negri Jakarta

Gulo, W. (2002). Metode Penelitian. Jakarta: PT. Grasindo.

Hamalik, Oemar.(2008). Perencanaan Pengajaran Berdasarkan Pendekatan Sistem. Jakarta:

Bumi Aksara.

Hurtoc, E B. (1999). Psikologi perkembangn suatu pendekatan sepanjang ruang kehidupan edisi 5. Jakarta : Erlangga.

Manullang ( 1991 ) pengembangan motivasi berprestasi . Jakarta, pusat produtivitas

Moh. Uzer Usman. (2008). Strategi Pembelajaran. Jakarta : Erlangga

Muhammad anfin ( 2004 ) kinerja guru pembimbing sekolah menengah umum.

Nana sudjana. (2002).Penilaian Hasil Proses Belajar Mengajar. Bandung: Remaja

Rosdakarya.

Nasional. Dapartemen Tenaga Kerja Republik Indonesia

Neni utami ( 2003 ). Kulalitas dan profesinalisme guru artikel di ambil pada tanggal 4 oktober 2007 dari http:/ /www.pikiran-rakyat.com/cetak/102/15/0802/html

Sahertian. (2008). Konsep Dasar dan Teknik Supervisi Pendidikan dalam rangka

Pengembanagan Sumber daya Manusia. Jakarta: Rineka Cipta.

Slameto. (2003). Belajar dan Faktor-faktor yang Mempengarubinya. Jakarta: Rineka Cipta.

Sutyadi prawirosentono (1999). Kebijakan kinerja karyawan, kiat membangun organisasi kompetitif menjelang perdagangan bebas. Yogyakarta: BPFE

Utami, Neni. (2003). Kualitas dan Profesionalisme Guru. Artikel dari: http://www.pikiran-rakyat.com/cetak/102/15/0802htm 